\title{
Kajian Kelayakan Pengembangan Kawasan Industri Di Mijen, Semarang - Indonesia
}

\author{
Feasibility Study on Industrial Estate Development in Mijen, Semarang - \\ Indonesia
}

\author{
Parfi Khadiyanto* \\ "Departemen Perencanaan Wilayah dan Kota, Fakultas Teknik Universitas Diponegoro Semarang, Indonesia
}

\begin{abstract}
Abstrak
Wilayah Mijen yang terletak di bagian Barat Laut Kota Semarang, adalah daerah yang memiliki tanah bergelombang, tetapi daerah ini ditetapkan sebagai kawasan pengembangan industri dalam Rencana Tata Ruang Kota Semarang 2011-2031. Pengertian pengembangan industri menurut Direktorat Jenderal Cipta Karya Departemen Pekerjaan Umum, yaitu pengembangan kawasan dengan penekanan utama pada kegiatan industri, baik di perkotaan maupun perdesaan, yang pada dasarnya untuk mewujudkan kondisi perkotaan dan pedesaan yang layak huni, aman, nyaman, damai, sejahtera dan berkelanjutan. Untuk mengantisipasi kejadian yang tidak diinginkan, perlu dilakukan kajian kemampuan lahan di wilayah Mijen yang direncanakan sebagai area pengembangan industri tsb, sehingga tidak terjadi pengembangan industri yang salah menempati suatu lahan.

Maka dari itu, tujuan penelitian ini adalah untuk menilai kesesuaian lahan untuk industri di Mijen Semarang, yang merupakan kawasan yang telah ditetapkan sebagai kawasan pengembangan industri, analisis yang digunakan adalah analisis SWOT dengan pendekatan analisis deskriptif kuantitatif. Hasil yang diperoleh menunjukkan bahwa Mijen cukup cocok dan layak untuk dikembangkan sebagai kawasan pengembangan industri, potensi utamanya adalah bahwa kawasan ini merupakan kawasan fungsi budidaya. Sedangkan yang paling melemahkan adalah kondisi lahan yang bergelombang.
\end{abstract}

Kata kunci: kesesuaian lahan, pengembangan industri, SWOT

\begin{abstract}
The Mijen area which is located in the North West part of Semarang City, is an area that has undulating land, but this area was designated as an industrial development area in the Semarang City Spatial Plan 2011-2031. Understanding of industrial development according to the Directorate General of Human Settlements of the Department of Public Works, namely the development of areas with the main emphasis on industrial activities, both in urban and rural areas, which are essentially to realize decent urban and rural conditions livable, safe, comfortable, peaceful, prosperous and sustainable. In order to anticipate unwanted events, it is necessary to examine the ability of land in the Mijen region which is planned as an industrial development area, not to allow the wrong industrial development to occupy the land

Therefore, the purpose of this study is to assess the suitability of land in Mijen Semarang, which is an area that has been designated as an industrial development area, the analysis used is a SWOT analysis with quantitative descriptive analysis approach. The results obtained indicate that Mijen is quite suitable and feasible to be developed as an industrial development area, the main potential being that this area is an area of cultivation function. While the most debilitating is undulating land.
\end{abstract}

Keyword: land suitability, industrial development, SWOT

\footnotetext{
* Parfi Khadiyanto

E-mail address: pkhadiyanto@gmail.com
} 


\section{Pendahuluan}

Pertumbuhan penduduk yang terus meningkat dan ketersedian lahan yang terbatas dengan karakteristiknya yang berbeda-beda merupakan sebuah masalah utama dalam pengembangan permukiman. Adapun pengertian pengembangan permukiman menurut Buku Panduan Umum Pengembangan Permukiman RPIJM (Rencana Program Investasi Jangka Menengah) dari Direktorat Jenderal Cipta Karya Departemen Pekerjaan Umum (2007) yaitu pengembangan permukiman baik di perkotaan maupun di perdesaan yang pada hakekatnya adalah untuk mewujudkan kondisi perkotaan dan perdesaan yang layak huni (livable), aman, nyaman, damai, sejahtera, dan berkelanjutan.

Penataan ruang merupakan salah satu instrumen di dalam perencanaan dan merupakan bagian dari sebuah perencanaan. Penataan ruang merupakan pedoman dalam perencanaan, pemanfaatan dan pengendalian ruang, selain itu perencanaan tata ruang adalah sebuah proses menentukan struktur ruang dan pola ruang yang meliputi penyusunan dan penetapan rencana tata ruang (Budhy, Tjahjati, 2011). Di Indonesia terdapat Undang-Undang yang mengatur tentang penataan ruang yaitu pada Undang-Undang nomor 26 tahun 2007. Di dalam undangundang tersebut terdapat aturan mengenai pembuatan dokumen Rencana Tata Ruang. Di dalam rencana tata ruang terdapat produk yang dinamakan dokumen tata ruang, dalam praktek penyusunan ruang di Indonesia, dokumen tata ruang bersifat hirarki mulai dari dokumen yang bersifat makro yang diberlakukan pada level nasional hingga dokmen yang paling detai hingga berlaku pada kawasan tertentu (Budiharjo, 2011). Rencana tata ruang tersebut merupakan acuan dari segala hal mengenai perencanaan, pemanfaatan dan pengendalian pemanfaatan ruang (Yunus, 2005).

Untuk memilih tempat tinggal, biasanya masyarakat tidak hanya melihat kondisi rumah itu sendiri sebagai bahan pertimbangan, tetapi juga memperhatikan kelengkapan dari sarana dan prasarana penunjang di kawasan tersebut (Khadiyanto, 2015). Karena pada hakekatnya, manusia tidak akan berdiam diri tetapi akan melakukan segala bentuk aktivitas untuk melangsungkan kehidupannya. Aktivitas tersebut dapat berupa aktivitas sosial, ekonomi, dan lain sebagainya (Raditya, 2011). Jika suatu wilayah atau kawasan permukiman memiliki kondisi permukiman yang layak huni, aman, nyaman, damai, sejahtera, dan berkelanjutan maka lokasi permukiman yang seperti itulah yang layak untuk dikembangkan sebagai lingkungan hunian, dan sebaliknya, apabila terdapat faktor yang dapat mengganggu atau mengancam keselamatan penghuninya, maka pemerintah dan pihak terkait lainnya harus mengambil sebuah solusi atau keputusan untuk memastikan keberlanjutan permukiman tersebut (Khadiyanto, 2016).

Semarang merupakan kota yang memiliki perkembangan kawasan yang cukup pesat dilihat dari pertumbuhan permukiman, perdagangan, dan jasa, maupun industrinya. Kota Semarang dibagi menjadi dua bagian kawasan yaitu Kawasan Semarang Bawah dan Semarang Atas. Kedua kawasan tersebut berbeda fungsi dimana Semarang Atas lebih difungsikan sebagai kawasan penyangga Semarang Bawah, sedangkan Semarang Bawah difungsikan sebagai pusat kota. Kecamatan Mijen merupakan salah satu kecamatan yang berada di bagian Kawasan Semarang Atas di sebelah barat utara kota. Kecamatan Mijen merupakan kecamatan yang difungsikan sebagai kawasan pengembangan untuk permukiman dan industri. Kecamatan ini juga menjadi kawasan penyangga untuk Semarang Bawah, khususnya bagian barat kota Semarang, karena di sini masih banyak terdapat kawasan hijau sebagai pelindung untuk mengantisipasi agar Semarang Bawah tidak terjadi banjir. Kecamatan Mijen merupakan kawasan yang padat dan dengan intensitas pembangunan yang tinggi, hampir disetiap kelurahan di Mijen ada proyek pembangunan, baik pembangunan permukiman, aktifitas ekonomi maupun jasa, yang merupakan kawasan pemekaran permukiman dan industri di bagian barat kota (Febriyaningsih, 2009).

Akan tetapi mengingat lahan yang ada di Mijen tidak datar, yaitu bergelombang, bahkan ada lereng yang cukup curam, maka perlu dikaji terlebih dahulu kesesuaian lahannya untuk pengembangan kawasan wilayah industri.

Setiap orang berhak untuk bertempat tinggal dan berusaha di wilayah yang layak huni, maka pengembang serta pemerintah kota berkewajiban untuk menyediakan lahan baik untuk industri dan permukiman yang harus layak untuk dihuni (Khadiyanto, 2005). Oleh karena itu perlu dilakukan analisis kesesuaian lahan untuk pengembangan permukiman berdasarkan kriteria-kriteria dasar yaitu, lahan harus berada pada kawasan budidaya, bukan daerah rawan 
bencana, relatif datar, tersedia sarana dan prasarana yang memadai, aksesibilitas mudah, jaringan air bersih tersedia.

Itulah pentingnya mengkaji ulang penetapan Mijen yang lahannya bergelombang, apakah benar lingkungan ini layak untuk dikembangkan sebagai kawasan pengembangan industri.

\section{Lokasi penelitian:}

Lokasi penelitian adalah di sekitar kawasan industri yang ada di Mijen, Kota Semarang. Lokasi ini dipilih, sebab perkembangan pembangunan industri yang terjadi saat ini tumbuh sangat pesat, hal ini terjadi karena lokasi terletak di tepi akses jalan utama (jalan provinsi) yaitu jalur jalan arah Jakarta - Semarang. Juga dekat dengan pusat pertumbuhan permukiman yaitu Bukit Semarang Baru, yang sudah memiliki bangunan rumah lebih dari 10.000 unit, lokasi dekat dengan terminal kota di Mangkang, serta memiliki fasilitas lingkungan lainnya yang lengkap.

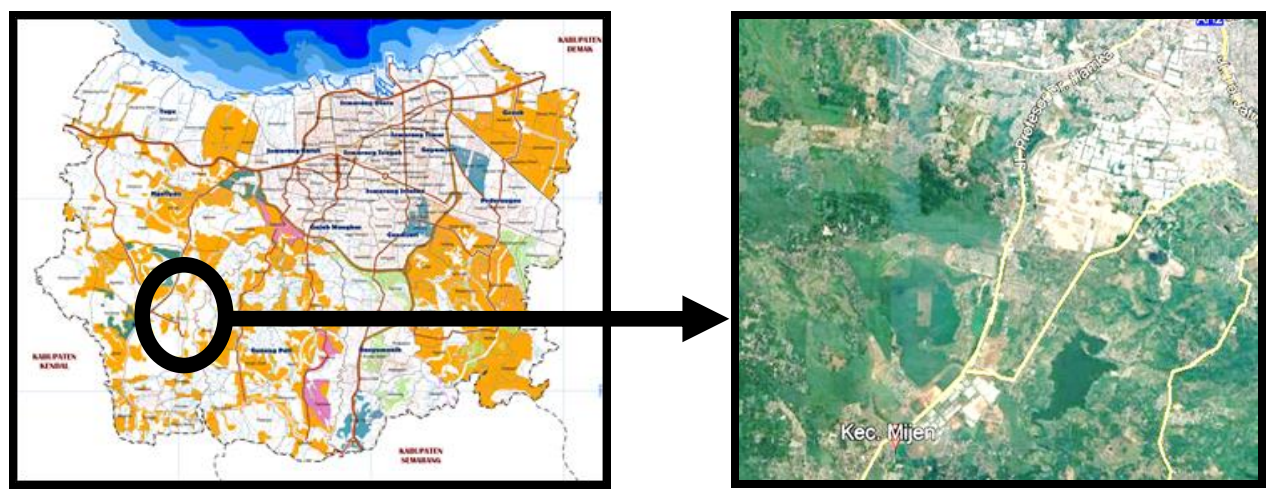

Gambar 1. Lokasi Penelitian Kawasan Industri Mijen

\section{Tujuan penelitian:}

Tujuan penelitian ini adalah untuk mengkaji kesesuaian lahan pada wilayah yang telah ditetapkan sebagai wilayah pengembangan industri di Mijen, dengan menggunakan analisis SWOT dan analisis deskriptif kuantitatif.

\section{Metode}

Pendekatan yang digunakan adalah pendekatan positifistik, deskriptif kuantitatif dengan menggunakan analisis SWOT. Dimulai dari mendeskripsikan wilayah penelitian, yang kemudian dilanjutkan dengan melihat aspek-aspek kekuatan dan kelemahan secara internal, dan peluang serta ancaman secara eksternal, yang semua itu di analisis melalui analisis SWOT untuk mengetahui kesesuai lahannya, guna pengembangan industri sesuai yang ditetapkan dalam RTRW Kota Semarang sampai dengan 2031.

Analisis pengembangan wilayah industri dalam penelitian ini merupakan akhir dari semua identifikasi yang dilakukan sebelumnya yaitu mulai dari identifikasi wilayah berdasarkan kesesuaian lahan, rawan bencana, ketersediaan sumberdaya air, kelerengan lahan, sebaran permukiman, sarana dan prasarana, serta jarak lokasi terhadap fasilitas pusat pelayanan kota.

\section{Kajian literatur}

Kesesuaian lahan dilakukan dengan menghitung nilai dari aspek erosivitas lahan, curah hujan, dan kemiringan lahan, apabila nilai total berada pada angka 125 ke bawah, maka kawasan tersebut berfungsi sebagai kawasan budidaya. Kerawanan bencana dilihat dari data series yang ada di lokasi, selama 30 tahun terakhir bencana alam apa saja yang telah terjadi. Ketersediaan sumberdaya air didapat dari survey langsung ke lapangan, dengan melihat dan wawancara kepada pengampu kebijakan kota dan masyarakat setempat. Sebaran industri di 
dapat dari peta guna lahan yang ada di tingkat Kecamatan dengan detail tingkat Kelurahan, untuk di cross-check dengan peta yang ada di Pemerintah Kota Semarang. Dalam tabel 1 sd 3 menunjukkan cara menganalisis suatu kawasan, apakah kawasan itu sebagai kawasan fungsi budidaya atau sebagai kawasan fungsi lindung yang mestinya tidak boleh dibudidayakan.

Tabel 1. Penilaian Kelas Lereng (Khadiyanto, 2015)

\begin{tabular}{lllll}
\hline No & Kelas Lereng & Kelerengan/Kemiringan & Sifat & Skor \\
\hline $\mathbf{1}$ & I & $0-8 \%$ & Datar & 20 \\
\hline $\mathbf{2}$ & II & $8-15 \%$ & Landai & 40 \\
\hline $\mathbf{3}$ & III & $15-25 \%$ & Agak Curam & 60 \\
\hline $\mathbf{4}$ & IV & $25-45 \%$ & Curam & 80 \\
\hline $\mathbf{5}$ & V & $>45 \%$ & Sangat Curam & 100 \\
\hline
\end{tabular}

Tabel 2. Penilaian Jenis Tanah Menurut Kepekaan Terhadap Erosi (Khadiyanto, 2015)

\begin{tabular}{llll}
\hline No & Jenis Tanah & Deskripsi & S kor \\
\hline $\mathbf{1}$ & Aluvial, tanah glay, planosol hidromorf kelabu, laterit air tanah & Tidak Peka & 15 \\
\hline $\mathbf{2}$ & Latosol & Kurang Peka & 30 \\
\hline $\mathbf{3}$ & Rown forensit soil, noncaltic brown, mediteran & Agak peka & 45 \\
\hline $\mathbf{4}$ & Andosol, Laterik, grumusol, podsolic, podsolitik & Peka & 60 \\
\hline $\mathbf{5}$ & Regosol, Litosol, oragonosol, renzina & Sangat Peka & 75 \\
\hline
\end{tabular}

Tabel 3. Intensitas Hujan Harian Rata - Rata dan Nilai Skor (Khadiyanto, 2015)

\begin{tabular}{lllll}
\hline No & Kelas & Interval (mm/hari) & Keterangan & Skor \\
\hline $\mathbf{1}$ & I & $0-13,6$ & Sangat Rendah & 10 \\
\hline $\mathbf{2}$ & II & $13,6-20,7$ & Rendah & 20 \\
\hline $\mathbf{3}$ & III & $20,7-27,7$ & Sedang & 30 \\
\hline $\mathbf{4}$ & IV & $27,7-34,8$ & Tinggi & 40 \\
\hline $\mathbf{5}$ & V & $>34,8$ & Sangat Tinggi & 50
\end{tabular}

Semua identifikasi yang telah dilakukan merupakan dasar dalam analisis untuk melihat kesesuaian lahan dalam pengembangan industri. Dalam analisis pengembangan permukiman ini terdapat dua hal yang akan dilakukan yaitu mengidentifikasi kekuatan, kelemahan, potensi, dan ancaman/ kendala yang ada yang disajikan dalam bentuk tabel selisih nilai total "KekuatanKelemahan" dan selisih nilai total "Peluang-Ancaman".

Selanjutnya yaitu melakukan rekapitulasi nilai berdasarkan sifatnya apakah nilai positif atau negatif untuk dimasukkan dalam kuadran posisi. Peletakan hasil hitungan dalam kuadran atau diagram SWOT disesuaikan dengan hasil nilai sumbu $\mathrm{x}$ dan sumbu y yang diperoleh dari perhitungan selisih S-W dan O-T. Sehingga bisa diketahui nilai potensi tingkat kesesuaian lahan untuk pengembangan industri. Diharapkan suatu lokasi yang layak bangun dengan tanpa kendala apapun bisa masuk dalam kuadran 1, yaitu memiliki potensi berupa peluang (misal kecukupan lahan) dan kekuatan (misal lahan fungsi budidaya). Bisa dilihat dalam gambar 2 di bawah bahwa apabila masuk wilayah kuadran 1 adalah yang paling baik, sedangkan untuk 
kuadran 2 posisinya sama dengan kudran 4, yaitu dalam kondisi bisa dikembangkan dengan syarat, sedangkan kalau masuk kuadran 3 maka tidak layak dikembangkan.

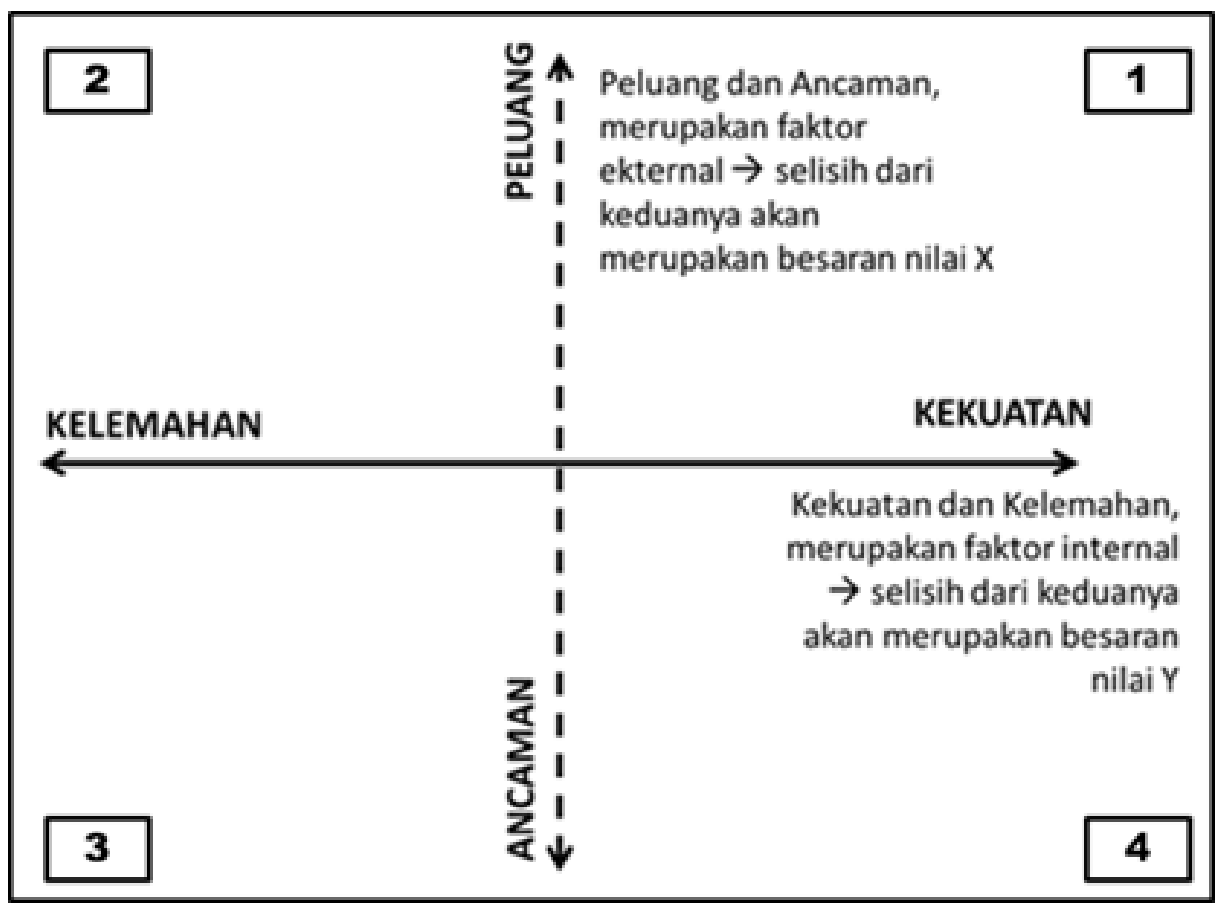

Gambar 2. Kuadran Analisis SWOT (Rangkuti, Freddy, 2013)

\section{Hasil dan Pembahasan}

Dengan melakukan penghitungan dari aspek curah hujan, yaitu dilihat dari data 30 tahun ke belakang, curah hujan di Mijen rata-rata sebesar $26 \mathrm{~mm} / \mathrm{hari}$, masuk dalam kategori sedang, dengan nilai $=30$. Untuk tingkat erosivitas yang ada di Mijen, masuk kategori kurang peka dengan nilai $=30$, sehingga gabungan dari dua kategori tersebut adalah sebesar 60 . Hal ini masih perlu dilihat kondisi kelerengan atau kemiringan tanah rata-rata di Mijen, dari hasil pemetaan yang dilihat melaui google earth, bisa dihitung kemiringan lahan berkisar antara 12$20 \%$, untuk pengamanan dalam penilaian, diambil nilai tertinggi, sehingga Mijen masuk kategori agak curam, dengan nilai $=60$. Jadi total seluruh nilai lahan guna penetapan fungsa kawasan, mencapai angka $30+30+60=120$.

Menurut Khadiyanto (2005) dinyatakan bahwa ada penetapan nilai lahan dari ketiga aspek tersebut sebagai berikut:

Tabel 4. Kriteria Penetapan Kawasan Lindung dan Budidaya (Khadiyanto, 2015)

\begin{tabular}{lll}
\hline No & Fungsi Kawasan & Total Nilai Skor \\
\hline 1. & Kawasan Lindung & $>175$ \\
\hline 2. & Kawasan Penyangga & $125-174$ \\
\hline 3. & Kawasan Budidaya & $<125$ \\
\hline
\end{tabular}

Sehingga bisa dinyatakan bahwa Mijen masih termasuk sebagai kawasan fungsi budidaya, diperkenankan secara fisik alamiah untuk dikembangkan sebagai permukiman. 


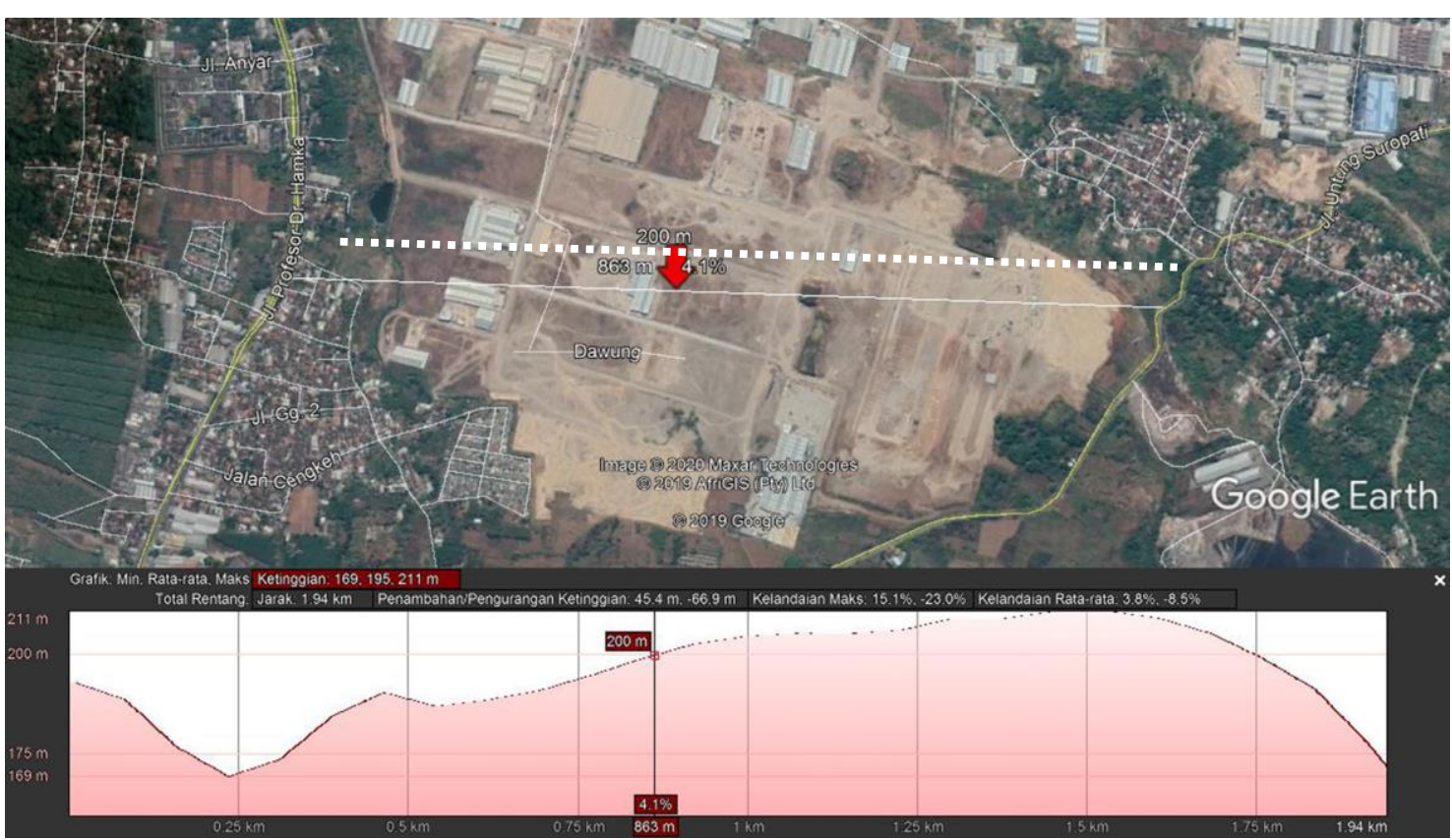

Gambar 3. Kondisi Kemiringan Lahan Wilayah Industri Di Mijen, Semarang

Dari temuan lainnya, yang berupa kedekatan dengan pusat pengembangan wilayah, dalam hal ini jarak Mijen dengan pusat permukiman hanya sekitar 3 (tiga) km, dianggap sebagai dekat. Sumber air untuk kebutuhan industri dalam proses pembangunan jaringan dari Perusahaan Air Minum Daerah Kota Semarang, yang diambil dari Waduk Jatibarang, sehingga sebagian saat ini masih menggunakan sumber air tanah, yaitu sumur artesis, dengan kedalaman sekitar 80-100 m dari permukaan tanah. Fasilitas sarana dan prasarana dasar belum lengkap, untuk fasilitas pendidikan masih menginduk kepada wilayah Mangkang dan Semarang Barat, dengan jarak sekitar $4 \mathrm{~km}$, demikian pula dengan fasiltas kesehatan masih terkonsentrsi di Semarang Bawah, yang berjarak sekitar $3 \mathrm{~km}$. Jaringan transportasi umum tidak menjangkau wilayah ini, tetapi jarak dari jalan raya utama yang menghubungkan jalur Jakarta - Semarang hanya berkisar 0,5 $\mathrm{km}$ saja. Dari perhitungan aspek internal yang dimilik, yaitu berupa kekuatan dan kelemahan, maka didapatkan hasil sebagai terlihat dalam tabel 5 berikut:

Tabel 5. Potensi Kekuatan Internal (Hasil Analisis, 2020)

\begin{tabular}{lc}
\hline KEKUATAN & nilai \\
\hline fungsi lahan budidaya & 0,8 \\
\hline kerawanan thd bencana (tak ada) & 0,45 \\
\hline ada cukup lahan untuk pengembangan & 0,3 \\
\hline akses mudah & 0,2 \\
\hline & $\mathbf{1 , 7 5}$
\end{tabular}

Sedangkan kelemahan yang terdapat dalam internal lokasi di Mijen adalah sebagai terlihat dalam tabel 6 berikut:

Tabel 6. Potensi Kelemahan yang ada di Mijen (Hasil Analisis, 2020)

\begin{tabular}{lc}
\hline KELEMAHAN & nilai \\
\hline lahan bergelombang & $-0,45$ \\
sarpras kurang & $-0,3$ \\
utilitas kurang & $-0,15$ \\
Jenis Industri bervariasi & $-0,1$ \\
air bersih sulit & $-0,3$ \\
\hline
\end{tabular}


Dari potensi internalnya yang dimiliki oleh Mijen dalam rangka untuk pengembangan permukiman secara total, yaitu merupakan penjumlahan nilai potensi kekuatan dengan nilai kelemahan, didapatkan hasil sebesar $=1,75-1,3=0,45$. Secara ekternal, maka dapat dilihat peluang dan ancaman yang terjadi, nilai dari peluang yang didapat berdasarkan temuan di lapangan adalah sebagai terlihat dalam tabel 7 berikut:

Tabel 7. Peluang pengembangan permukiman di Mijen (Hasil Analisis, 2020)

\begin{tabular}{lc}
\hline PELUANG & nilai \\
\hline dekat dengan pusat pengembangan lingkungan & 0,6 \\
\hline tidak mempengaruhi kawasan sekitarnya & 0,6 \\
\hline & $\mathbf{1 , 2}$ \\
\hline
\end{tabular}

Secara ekternal, untuk nilai ancamanyang ada di Mijen dalam rangka pengembangan sebagai wilayah permukiman, bisa dilihat dalam tabel 8 di bawah ini:

Tabel 8. Nilai ancaman yang ada di kelaurahan Mijen (Hasil Analisis, 2020)

\begin{tabular}{lc}
\hline ANCAMAN & nilai \\
\hline tidak dilalui transportasi umum & $-0,6$ \\
\hline tak ada jaringan persampahan & $-0,4$ \\
\hline & $\mathbf{- 1}$ \\
\hline
\end{tabular}

Dari potensi ekternalnya yang dimiliki oleh Mijen dalam rangka untuk pengembangan industri secara total, yaitu merupakan penjumlahan nilai potensi peluang dengan nilai ancaman, didapatkan hasil sebesar $=1,2-1=0,2$. Meskipun relatif kecil, yaitu tidak mampu mencapai angka 0,5 ; tetapi hal ini masih menunjukkan sebuah potensi positif, secara diagramatis dapat dilihat dalam gambar 6 sebagai berikut:

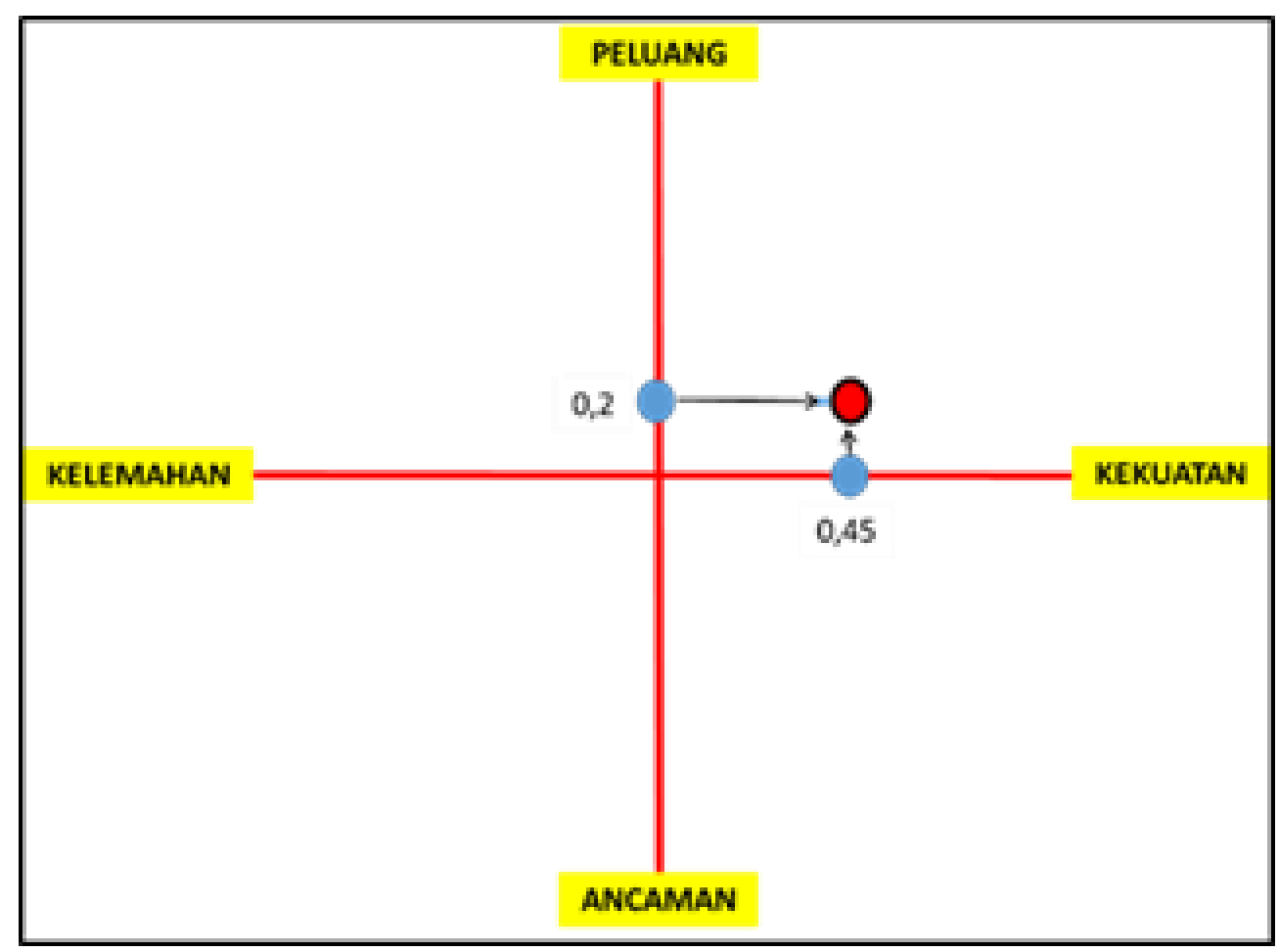

Gambar 4. Posisi hubungan faktor internal dan eksternal, untuk pengembangan industri di Mijen, Semarang (Hasil Analisis, 2020) 
Posisi ekternal antara peluang dibandingkan dengan ancaman, masih memiliki nilai positif yaitu sebesar +0,2 sebagai sumbu X. Sedangkan posisi internal antara kekuatan dan kelemahan yang dimiliki, masih besar nilai kekuatannya yaitu $+0,45$ sebagai sumbu Y. Maka posisi potensi kawasan untuk dikembangkan sebagai wilayah pengembangan industri termasuk layak, yaitu berada pada kuadran 1 (satu) yang artinya semua komponen adalah baik untuk dikembangkan (progresif).

\section{Kesimpulan}

- Mijen adalah kawasan yang sesuai dan layak untuk dikembangkan sebagai wilayah pengembangan industri, potensi utamanya adalah bahwa kawasan ini merupakan kawasan fungsi budidaya. Sedangkan yang paling melemahkan adalah lahan yang bergelombang.

- Saat ini, sarana dan prasarana dasar memang masih kurang, akan tetapi sejalan dengan perkembangan wilayah, pasti akan tumbuh banyak investor yang akan membangun sarana dan prasarana dasar yang bekerja bersama dengan pemerintah daerah.

- Secara keselurah nilai potensi pengembangan tidak begitu tinggi, tetapi hasilnya tetap positif, yaitu masuk kategori bisa dikembangkan (progresif).

\section{Ucapan terima kasih}

Terima kasih saya ucapkan kepada seluruh rekan di Laboratorium Rancang Kota atas segala bantuannya, juga kepada aparat Pemerintahan Kecamatan Mijen, khususnya para pengurus dan Ketua LPMK Kelurahan yang ada di Mijen yang telah banyak memberikan masukan tentang kondisi lapangan, dan juga kepada staf kantor Kecamatan yang menemani survey lapangan, dan mengenalkan kepada beberapa pemilik industri/pabrik serta warga untuk bisa diajak wawancara. Kepada staf Laboratorium Rancang Kota, yaitu Santi Dewantari, terima kasih atas bantuan pengetikannya sehingga laporan ini bisa selesai tepat waktu.

\section{Referensi}

Akhnoer.(2018).Tata Ruang. http://akhnoer.wordpress.com/2008/12/06/tata-ruang/ (diunggah Desember 2018)

Budhy, Tjahjati Soegijoko, dkk. (2018) Bungai Rampai Pembangunan Kota Indonesia Dalam Abad 21. Buku 1 "Pengalaman Pembangunan Perkotaan di Indonesia". Penerbit: Urban and Regional Development Institute (URDI) dan Yayasan Sugijanto Soegijoko bekerjasama dengan Lembaga Penerbit Fakultas Ekonomi Universitas Indonesia, Jakarta. Cetakan ke 4

Budiharjo, Eko. (2017). Penataan Ruang dan Pembangunan Kota: PT.Alumni. Bandung, Cetakan ke 6

Direktorat Jenderal Cipta Karya Departemen Pekerjaan Umum (2007) Laporan Akhir Kajian Pengembangan Perumahan dan Permukiman Di Kabupaten/Kota. Kementrian Pekerjaan Umum dan Perumahan Rakyat Republik Indonesia, Jakarta.

Dessy Eresina Pinem, April 2016, Menemukan Strategi Pengembangan Kawasan Industri Melalui Analisis Sektor Unggulan Kota Binjai, (diunggah Juli 2019) https://www.researchgate.net/publication/307548314_Menemukan_Strategi_Pengembangan_Kaw asan_Industri_Melalui_Analisis_Sektor_Unggulan_Kota_Binjai

Febriyaningsih, Laeli. "Profil Kelurahan-Kelurahan di Semarang". Juni 2009. http://laeli-deanovafebri.blogspot.com/2009/06/profil-kelurahan-semarang.html

Haryono, Imam, 2016, Pembangunan Kawasan Industri Dalam Rangka Percepatan Penyebaran Industri, pidato/makalah yang disampaikan pada Rapat Kerja Kementerian Perindustrian Jakarta, 16 Pebruari 2016

Khadiyanto, Parfi (2015); Tata Ruang Berbasis Pada Kesesuaian Lahan; Badan Penerbit UNDIP, Semarang

Khadiyanto, Parfi (2016); Correlation Between Quality of Environment and Quality of Life, in Trimulyo Village, Genuk Sub District, Semarang City, Indonesia; IOSR Journal of Humanities and Social Science (IOSR JHSS), vol 21 - issue 9, September 2016

Peiser, Richard B with Dean Schwanke. Professional Real Estate Development. Washington D.C.: the Urban Land Institute, 2014, hal. 265-307. 
Properti Editorial, 2005 “Kawasan Industri Surabaya: Mengintip Investor di Kota Buaya,” Properti, No. 20, September 2005, hal. 54-55

Raditya, Denny.(2011). Pengertian Umum Mengenai Perencanaan Wilayah dan Kota. http://dennyraditya73.wordpress.com/2011/09/27/pengertian-umum-tentang-perencanaan-wilayahdan-kota/ (diunggah 27 September 2007)

Rangkuti, Freddy. 2013. Analisis SWOT, Cara Perhitungan Bobot, Rating, dan OCAI. Jakarta : PT Gramedia Pustaka

Sastrowardoyo, Sanyoto. Pengembangan Kawasan Industri Dalam Rangka Menarik Penanam Modal. Makalah disampaikan pada Rapat Kerja Himpunan Kawasan Industri, Surabaya, Oktober 2001.

Soedarso, 2001, Kebijakan Pengembangan Kawasan Industri, https://perencanaankota.com/2014/08/kebijakan-pengembangan-kawasan-industri.html, diunggah Nopember 2018

Shahab, Halim. "Perkembangan dan Prospektif Bisnis Kawasan Industri di Indonesia." Jurnal Infopapan, April 2012, hal. 17-20.

Yunus, H.S.(2015). Manajeman Kota Perspektif Spasial. Yogyakarta : Pustaka pelajar. Pencetak : Pustaka pelajar offset. Cetakan 8 september 2015.cetakan 2 mei 2008 pp.2005.63 